\title{
Reproductive Physiology of Male Rabbits: A Key Factor in Buck Selection for Breeding (Paper Review)
}

\author{
Chikaodiri H. Onuoha \\ Instititute of Agricultural Research and Training, Obafemi Awolowo University, Moor Plantation, Apata Ibadan, Nigeria \\ Email: chikaodiri4change@yahoo.com
}

How to cite this paper: Onuoha, C.H. (2020) Reproductive Physiology of Male Rabbits: A Key Factor in Buck Selection for Breeding (Paper Review). Advances in Reproductive Sciences, 8, 97-112. https://doi.org/10.4236/arsci.2020.82009

Received: February 11, 2020

Accepted: March 28, 2020

Published: March 31, 2020

Copyright $\odot 2020$ by author(s) and Scientific Research Publishing Inc. This work is licensed under the Creative Commons Attribution International License (CC BY 4.0).

http://creativecommons.org/licenses/by/4.0/

\section{(c) (i) Open Access}

\begin{abstract}
Rabbits are unique animals found in many different continents and climatic zones. Domestic rabbits are the descendants of Oryctolagus cuniculus, a species native to the western Mediterranean basin (Spain and North Africa) and it is said to have originated from the European wild rabbit. Rabbits have been used as experimental animals in genetics and breeding since the beginning of the century. Rabbit bucks are ready for reproduction at 32 weeks of age when sperm production is known to have stabilized. Lack of detailed information about the anatomy and morphological structures of rabbit bucks, their reproductive organs and its physiology, hampers the reproductive index in multiplication and breeding of rabbits. This review is centered on gathering relevant information about the morphology and reproductive physiology of rabbit bucks with emphasis on showing some aspects relating to their sexual maturity, occurrence of puberty, reproductive distinctiveness, seminal characteristics, number, size of glands and their location, sperm production and Spermatogenesis for a better breeding purpose.
\end{abstract}

\section{Keywords}

Rabbit Buck, Reproduction, Anatomy, Morphological Structure, Physiology, Breeding

\section{Introduction}

There are about 38 breeds and 19 strains of domestic rabbits throughout the world recognized by (ARBA) American Rabbit Breeder Association [1]. Rabbit breeds are distinguished by varying characteristics such as size, shape, colour of eyes, colour of hair coat (fur) and weight [2] [3]. Most breeds are created by humans 
and are no older than 200 or 300 years which is why there are few locally adapted Landraces. Rabbit breeds can be identified in terms of gene frequencies, this is possible with genes identifiable through their major or visible effects such as colouration and hair structure [4].

Breeds of rabbit are grouped by adult size and origin. Those grouped by their origin are: 1) The geographic and primary or primitive breed: These are those breeds from which all other breeds emanated from breeds such as Fauvede Bourgogne, Argenté de Champagne. New Zealand White and Red, are the kind obtained through artificial selection from this group. 2) The Synthetic breeds: This kind of breeds are obtained by planned crosses of several breeds examples are the Blancdu Bouscat and Californian; Mendelian breeds obtained by the fixation of a new character of simple genetic determination, appeared by mutation, example of such are Castorrex, Satin and Japanese [4].

Secondly are the breeds of rabbit conveniently grouped by adult size, which is also related to production characteristics such as precocity, prolificacy, growth rate and age at maturity. A major determinant of adult size is the origin of the breed. These groups are:

\subsection{Heavy Breeds}

Adult weight exceeds $5 \mathrm{~kg}$. Fertility is generally low. The growth potential of the heavy breeds can be exploited, especially in cross-breeding. The Bouscat Giant White, (French) Belier, Flemish Giant and French Giant Papillon are examples. The fur of the (French) Belier varies greatly in colour and can be white, agouti, iron grey or black. Its body build would make it a good meat rabbit. However, it is bred for show and therefore found only in small units, at least in France. The breed is more important in other European countries such as Germany and Denmark. The Bouscat Giant White is a synthetic albino breed. It is a large rabbit known for its prolificacy and fast growth rate in traditional French rabbitries. The Flemish Giant from Belgium comes in several colours. It is one of the largest rabbits (potential adult weight $7 \mathrm{~kg}$ ) and is still farm-raised. This breed could furnish a gene pool for improving growth in other breeds; Flemish Giants could be pure-bred for reproduction purpose [4].

\subsection{Average Breeds}

Adult weight varies from 3.5 to $4.5 \mathrm{~kg}$. These are the basic stock of breeds used for intensive rabbit production for meat in Western Europe and are the most numerous. The Silver rabbits fall in this category. They are found in several countries (English Silver, German Silver). These varieties differ from the Argenté de Champagne in adult size (English Silver is lighter) and in colour. Argenté de Champagne is an example of a breed that has developed with selection over many years from a regional population (Champagne). The breed is known for both its fur, once much sought after, and its productivity: high fertility, quick growth, good muscle development and good meat quality. Its adult weight is 4 to $4.5 \mathrm{~kg}$. It is farm-bred in France, usually on straw litter [4]. 


\subsection{Lightweight Breeds}

These breeds have an adult weight of 2.5 to $3 \mathrm{~kg}$. They include the Small Himalayan, the Small Chinchilla, the Dutch and the French Havana. The Russian or Himalayan rabbit is white with black extremities. It is thought to have originated in China and spread from there to Russia and Poland. It carries the Himalayan $\mathrm{Ch}$ gene mutation. The lightweight breeds usually develop very quickly and make excellent mothers. They eat less than the medium and large breeds and could be crossed or used pure in developing countries to produce a light, meaty carcass of 1 to $1.2 \mathrm{~kg}[4]$.

\subsection{Small Breeds}

These breeds weigh about $1 \mathrm{~kg}$ at maturity. They are represented chiefly by the Polish rabbit, with its many variations of coat colour. Selection for small size has led to very low fertility and a marked decrease in growth rate. These breeds cannot be used for meat production. They are bred for show, for the laboratory and as pets. Local populations and strains Pure-bred animals are usually raised in small groups and their selection for breeding characters is in its infancy. These breeds could therefore constitute interesting potential gene pools for improving local populations. They are "common" rabbits, grey, spotted or white, the outcome of various unplanned crosses. They may belong to local populations. Some examples of local populations in developing countries are the Baladi rabbit of the Sudan (baladi means native or local in Arabic), the Maltese rabbit of Tunisia and the Creole rabbit of Guadeloupe [4].

Some of the common internationally recognized breeds that have successfully adapted to the African tropical environment are the Chinchilla, New Zealand White, Flemish giant, white California, Champagne D' Argent, Britannia petite, Belgian hare, Cinnamon, Creme D' Argent and Dutch rabbit [2] [3].

The Large Chinchilla rabbit raised in Europe is of German origin. Its adult weight averages $4.5 \mathrm{~kg}$. It can be bred for meat and fur.

The Flemish Giant from Belgium comes in several colours. It is one of the largest rabbits (potential adult weight $7 \mathrm{~kg}$ ) and is still farm-raised. This breed could furnish a gene pool for improving growth in other breeds.

The Californian is a synthetic American breed. It was presented for the first time in 1928 in California by its breeder, whose objective was a meat animal with very good fur. The adult weight of the Californian is 3.6 to $4 \mathrm{~kg}$.

The New Zealand White originated as a breed in the United States. It is the albino offspring of coloured rabbits. From the outset it was bred selectively in large meat production units, especially in southern California (San Diego area) for its breeding qualities: prolificacy, maternal performance, fast growth rate and precocious body development which makes it ready for slaughter at 56 days, the objective being a light carcass. The New Zealand White adult weight $(4 \mathrm{~kg})$ slightly exceeds that of the Californian. 
The Fauve de Bourgogne is an example of a breed that has developed with selection over many years from a regional population. It is also of regional origin. It has spread throughout France and elsewhere in Europe (Italy, Belgium, Switzerland).

Argenté de Champagne is an example of a breed that has developed with selection over many years from a regional population (Champagne). The breed is known for both its fur, once much sought after, and its productivity: high fertility, quick growth, good muscle development and good meat quality [4].

Breeds of rabbit has significant influenced on their maturity as some are noted for early sexual maturity while some are known for late maturity [3]. The prolific nature of rabbits coupled with its short gestation period and generation interval, makes it the animal of choice for multiplication and a short way of increasing animal protein intake [5]. It is imperative that we understand the physiology of reproduction in buck as it relates to their anatomy and physiological characteristics with cognizance to different breeds of rabbit, hence the aim of this review which is to update our knowledge on the key factor in selection of rabbit buck for breeding.

\section{Materials and Method}

A structured literature searches in Scopus (http://www.Scopus.com/home.url), Researchgate (http://researchgate.com), google (http://www.google.com), Yahoo (http://www.yahoosearch.com), and Askjeeves (http://www.askjeeves.com), were carried out using different search topics relating to reproduction, physiology and breeding in rabbit. Publications relevant to the title of this review based on abstract screening were selected and used. Agricultural related Bulletin and Textbooks (hard and e-copy) having topics relevant to this review were also used. Other related peer-reviewed papers from reference list in the selected publications were also considered. Experimental studies which centered on the evaluation and assessment of the effects of feeds, synthetic androgenic substance and additive on reproductive performance of rabbit using control animal groups, were also selected and only those publications written in English were used in this review.

\section{Results}

About 45 scientific publications including textbook write ups which reported studies that focused on reproduction, physiology, anatomy, sexual maturity, breed and semen characteristics of rabbit were evaluated. The overview of the experimental studies and write-ups that were described in these publications which are being referenced at the end of the review write-ups, were summarized below in captions.

\subsection{Reproductive Anatomy}

Reproductive organs are not unconditionally necessary for the individual life but they have an essential role in the reproduction and life of species [6] [7]. They 
are dynamic organs in an animal of which proper understanding of the anatomy and physiological characteristics increases efficiency and production as they reflect very sensitively various changes in the environment [7] [8]. Many times they are the only organs which at low toxicity show structural and functional changes [9] [10].

The reproductive system of rabbit buck (Figure 1) consists of the testes (2) which weighed over 6 grams in some breeds [11], epididymis (2), ampoules (2), Vas deferens (2), urethra, penis, preputial glands (2), accessory glands, a well-developed scrotum located adjacent to the penis and the urogenital opening [12] [13].

\subsubsection{Scrotum}

The testicles are housed in the scrotum. The scrotum is formed by the tunica vaginalis, tunica dartos and cremaster muscle and said to have few hairs [14]. Its main function is to keep the testicles away from the abdominal cavity so that the right testicular temperature is maintained between $0.5^{\circ} \mathrm{C}$ and $4^{\circ} \mathrm{C}$ below body temperature as required for normal spermatogenesis [15]. The scrotum and abdomen have communication through the inguinal ring which conveys the excretory duct (vas deferens) that comes from the epididymis.

\subsubsection{Penis}

The penis is the copulatory organ. An unusual feature of the rabbit is the absence of glans in the penis [16] but the body of the penis is cylindrical, $40-50 \mathrm{~mm}$ long and the diameter decreases at its end. During rest from sex, the penis lies in the foreskin located ventrally to the anus [15] [16] and caudally to the testicles [13].

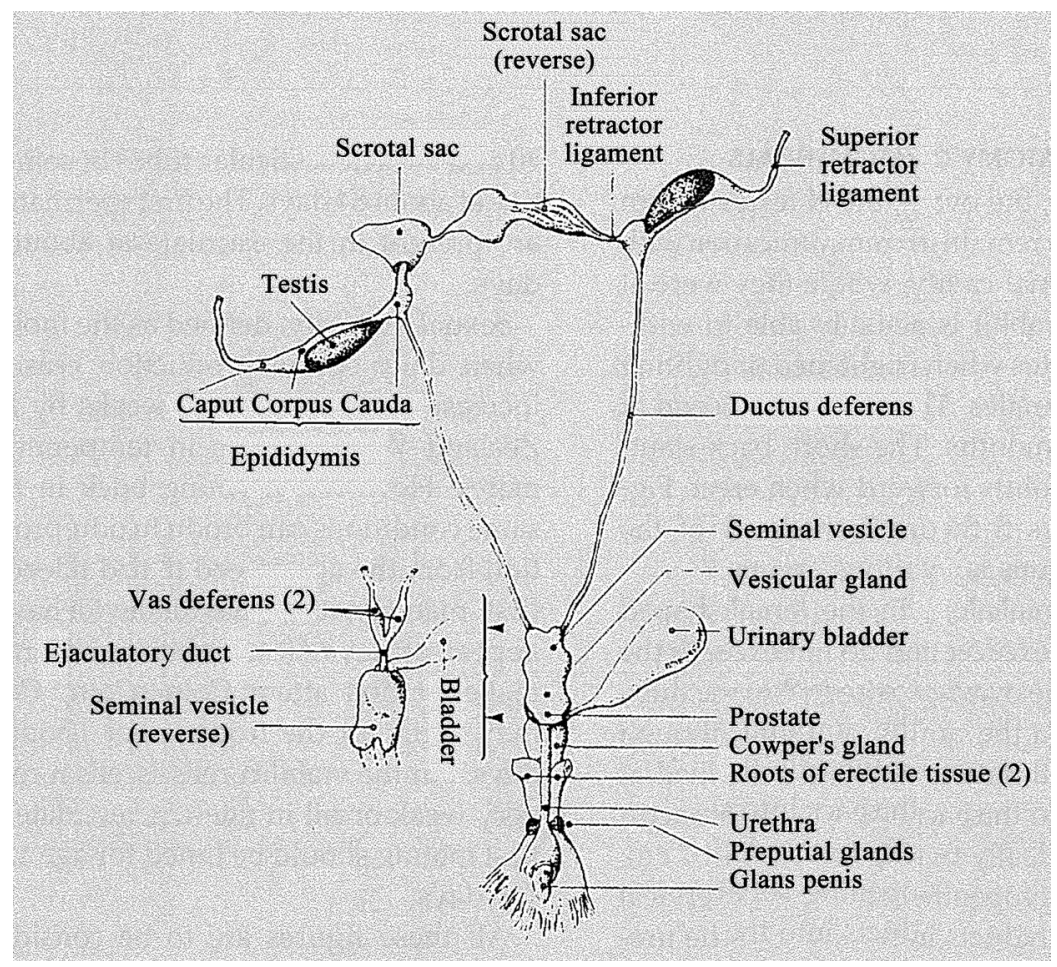

Figure 1. Genital anatomy of the male rabbit. Source: [4]. 


\subsubsection{Epididymis}

The epididymis is the place where sperm produced are stored before being released during ejaculation. Its functional part consists of a single duct. The epididymis originates in the efferent ducts; highly curled over the head, body and tail and connects straight to the vas deferens. It is noted by some authors that the tail of the epididymis is in the shape of a $U$ [17]. The rabbit is one of the species in which sperm stored in the cauda epididymis exhibit vigorous motility even in their own fluid [18].

\subsubsection{Vas Deferens}

The vas deferens extends dorsal-cranial to the body of the epididymis through the inguinal canal and enters in the abdominal cavity. The final portion of the vas deferens forms a loop around the ureter and at this point becomes fusiform. Although the thickness of the diameter does not differ from the rest of the vas deferens, this segment is generally called ampulla (ampulla vas deferens) [17].

\subsubsection{Urethra}

The urethra is a large canal that leads through the penile organ to the outside of the body. It is the connection point at which the two vas deferens ducts converge from the left and right sides of the body to connect at its upper end; very near to where the urinary bladder opens into the urethra [12].

\subsubsection{Testes}

The testis of the buck is oval-shaped. It is the main source of testosterone in rabbits [19] which is the main androgen produced during sexual maturation [20]. They are positioned cranially to the penis [13] [16], located in the scrotum, each one on one side of the inguinal line and positioned almost horizontally [17]. After birth, the testes develop less quickly than the rest of the body. From the age of five weeks, they begin to grow very rapidly. The rabbit's testicles descend at about two months and they are said to be similar to those of cats but can move freely from the scrotum to the abdomen through an opening in the inguinal canal [16]. The testicles continue to grow and increase sperm production until six (6) months of age [21]. The position of the testicles depends on many factors including body position, body temperature, reproductive activity, repletion of the gastrointestinal tract, amount of abdominal fat [13] and stress [22]. During periods of sexual inactivity or stress, the testicles return to the abdominal cavity through the inguinal ring and may go down again by the action of the cremaster muscle [13] [15]. According to Fraser [23], the appearance and testis weight depend on the location. For example testes located in the scrotum are heavier, firm in texture and red in colour. Abdominal testes are light, reddish-brown and limp. Although their essential function is the maintenance of normal spermatogenesis, serum testosterone above the baseline level do not appear to influence the efficiency of spermatogenesis [19]. 


\subsubsection{Accessory Glands}

The accessory sex glands are complex (Figure 2). They secrete many compounds found in the semen of other mammals such as fructose, citric acid, glycerylphosphorylcholine, and minerals [24] Secretion of catalase [25] is uniquely high in rabbit semen. The accessory sex glands respond differentially to androgens and estrogens [26] and the weights of this organ are a bio-indicator of circulating steroid hormone levels. Accessory glands in the rabbit develop less quickly than the rest of the body just like the testes but at a more even rate and are less precocious. The glands of the rabbit's reproductive tract differ in number, location, size and proportion among other aspects like those in other mammals. This set of glands consists of a vesicular gland, bulbourethral gland and prostate gland [27] and Vasquez [28] affirm that the prostate consists of three lobes: Proprostate, Prostate and Paraprostate. According to [29], they contribute to the greater part of the volume of ejaculate. Each part of the gland plays a specific role in reproduction [30].

\subsubsection{Prostate Gland}

The prostate gland is yellowish-white in colour and is located caudally to the vesicular gland and found in between the Pro prostate and bulbourethral glands. It shares the same connective tissue capsule as the pro prostate; only a small layer of tissue separates these two glands. The paraprostate glands are small and were named as such because they are located on both sides of the prostate [27]. They have an irregular embossed surface and are hammer-shaped [28].

\subsubsection{Bulbourethral Gland}

The bulbourethral gland of the rabbit is a small mass of glandular tissue that is surrounded by a capsule and widely covered by skeletal bulb glandular muscle that separates it into lobules. This gland originates in the urethral wall, as distinct from other species. It is fairly small in rabbits but relatively larger than that of a man [31].

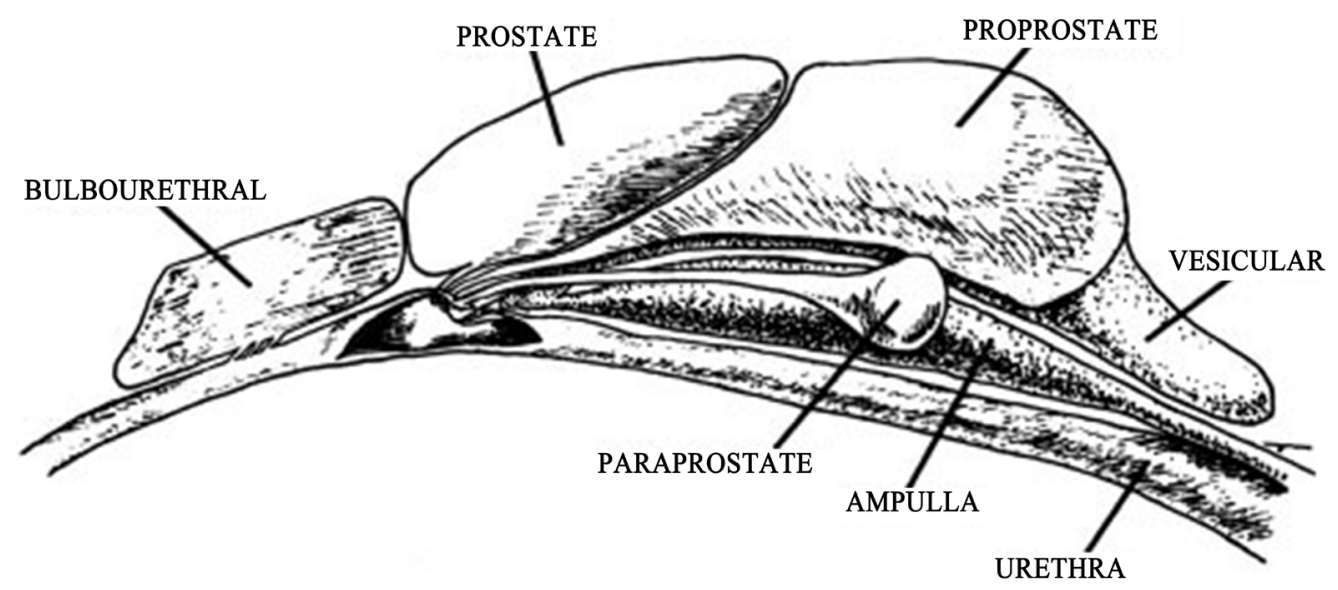

Figure 2. Midsagittal section through the urethra and the accessory sex glands of the domestic male rabbit. With the exception of the ejaculatory duct from [17] (all ducts are paired). 


\subsection{Reproductive Physiology}

The onset of reproductive cycle marks the attainment of puberty depending on the level of feeding and breed. This is about $4-5$ months in light breeds [32]. At puberty, the reproductive organs are fully developed. The testicles are housed in the scrotum. The male sex cells are formed in the tiny seminiferous tubules which are basically two-ended loops with two ends opening into the rete testis, each tubule is extensively convoluted and an appreciable proportion is branched so that they have three openings into the rete testis. The sperm from each testicle then passes through very small tubes into an epididymis, each epididymal tube leads to longer tubes which are the vas deferentia. The two vas deferens ducts converge from the left and right sides of the body to connect with the urethra canal at its upper end very near to where the urinary bladder opens into the urethra. The urethra is a large canal that leads through the penile organ to the outside of the body [2].

\subsubsection{Puberty and Sexual Maturity}

Rabbits are well known for their ability to reproduce quickly. The onset of puberty varies greatly with breed but conditions in the rabbitry also play an essential role, particularly feeding, which is even more important than climate [4]. Around six (6) weeks of their age, there is a quick increase in Follicle stimulating hormone (FSH) and Luteinizing hormone (LH) concentrations in the blood which precede the onset of testosterone secretion and consequently the manifestation of puberty [20]. [33] reported that rabbits are pubertal when their testicles become androgenically active and accessory glands begin to produce fructose and citric acid then the animal is said to characteristically assume male behaviour. He affirmed that at 63 days of age, rabbit testes descend into the scrotum. Studies revealed that although rabbits are pubertal in 4 months, the testes are not in the scrotum yet, as the descending into the scrotum is observed only at six months of age [23].

\subsubsection{Sexual Maturity}

Sexual maturity is defined as the moment at which the daily spermatozoa production ceases to increase [4] [34]. A buck attains sexual maturity when its daily sperm production stabilizes and becomes able to fertilize the females. This is witnessed at the end of the $32^{\text {nd }}$ week of existence in the New Zealand White breed raised under temperate environment [35]. In rabbits, sexual maturity varies with age (125 - 150 days), breed, lineage, food/feeding and environmental factors such as photoperiod, temperature and seasonality. Sexual precocity is more developed in small or medium breeds (4-6 months) than in larger breeds (5- 8 months). Studies have shown that the New Zealand White reaches sexual maturity at 18 weeks of age [20] [36]. This is maintained first as the rabbit attempts riding at 70 - 90 days after birth. It is argued however, that the ejaculates are low in viability hence bucks of about 135 - 140 days of age should be used for mating when the viability of the ejaculate is believed to have stabilized [37]. 


\subsubsection{Spermatogenesis}

Spermatogenesis begins with the formation of spermatogonia stem and the lifetime of such stem cells is a cycle of seminiferous epithelium. Spermatogenesis in rabbits starts at $7-8$ weeks (between 42 and 63 days of age) by the division of spermatogonia but semen do not appear in ejaculated sperm before 119 days [33]. Spermatogenesis is a process that depends on the low temperature of the scrotum thus temperatures higher than that of the scrotum (e.g. abdominal temperature) may block the process [38]. The total estimated duration of spermatogenesis in rabbits depends on the point chosen as the beginning of spermatogenesis. Assuming that spermatogenesis begins with the first part of a series of division of spermatogonia leading to the production of primary spermatocytes, then about four cycles of the seminiferous epithelium $(4 \times 10.9=43.6$ days $)$ are required. [39] reported that during spermatogenesis there is considerable loss of spermatogenic cells in the rabbit and that most of this loss occurs during and immediately after the two maturation divisions. However, recent studies have demonstrated the presence of round spermatids in the epididymis (sloughing of spermatids). In other words, they leave the testes before maturation [40]. The authors also suggested that the age of the animal and season contribute to the sloughing of spermatids which may occur more frequently after puberty or when spermatogenesis begins to occur in an active form [40].

\subsubsection{Sperm Production}

Sperm production begins at puberty. The testicles continue to grow and increase sperm production until six months of age [21]. The volume of semen ejaculated is about 0.3 to $0.6 \mathrm{ml}$. Concentration is evaluated at 150 to $500 \times 10^{6}$ spermatozoa per $\mathrm{ml}$, but both volume and concentration are liable to vary. Maximum spermatozoa production is obtained by using the buck regularly once a day. If the buck is used regularly twice a day, each ejaculate has only one half the concentration of spermatozoa. On the other hand, if bucks service several times a day, one day a week, the three or four ejaculates may be concentrated enough to effect fertilization [4]. Spermatozoa can already be present in the cauda epididymis at around 15 weeks of age [20]. Daily spermatozoa production is roughly 150 to 300 million, independent of the rate of ejaculation. It is also noted that daily spermatozoa production increases from 15 to 52 weeks of age [4]. However, daily exposure to a continuous 14 hour light period negatively affects gonadal reserves [41]. According to the author, under normal conditions, the average yield is $147.4 \times$ $10^{6} /$ day and $1 \mathrm{~g}$ of testis produces $26.5 \times 10^{6}$ spermatozoa/day. However, if the animal is subjected to a rate of two weekly collections, the daily release of spermatozoa in the ejaculate is consistently lower than the testicular production, indicating that approximately $50 \%$ of the spermatozoa produced are reabsorbed (Holtz and Foote, 1972). Different daily production of spermatozoa has been observed: $148 \pm 11 \times 10^{6}$ spermatozoa per day [34], $187 \times 10^{6} /$ day [42] and $210 \times$ $10^{6} /$ day [43]. A recent study showed that in the New Zealand White breed, the spermatozoa reserve is smaller in the left testis and left epididymis than in the right ones [44]. 


\subsubsection{Sperm Motility}

Percentage of spermatozoa moving steadily in a straight line for species with internal fertilization is called motility and it is a common feature of spermatozoa in all animals [45]. Motility is important for the transport of spermatozoa in the reproductive tract and oocyte penetration [46]. Subjective estimation of the evaluation of motility and sperm morphology are the two most widely used laboratory tests to evaluate semen in rabbits [47]. These characteristic results in potential spermatozoa fertility as there are some correlations between seminal parameters with motility indicating the relationship between morphometric parameters and semen quality of rabbits [48] [49].

\subsubsection{Semen Characteristics}

Rabbit semen consists of two main parts; a fluid and a gelatinous portion [50]. The semen is a mixture of spermatozoa produced by the testes and seminal plasma secreted at the time of ejaculation by the epididymis and different accessory glands combined [51]. The fluid portion of the semen is represented as the seminal plasma. It contains constituents such as carbohydrates, lipids, proteins and minerals that are important for sperm metabolism. Their presence positively affects the survival and parameters of spermatozoa motility in rabbits [52] [53]. Rabbit seminal plasma contains sodium (Na), Potassium (k), Calcium (ca), Magnesium (mg), Selenium (se), Zinc (zn) [54] and some trace elements such as Copper, iron, Manganese, Cadbuim, Lead and Nickel [55]. The gelatinous mass or gel from rabbit semen originates in the vesicular [56] and it is androgen-dependent [57]. It contains a significant amount of oestrogenic substances, citric acid and small amounts of fructose [24] [50]. [58] recommends that the gel be removed immediately after collecting the rabbit semen before its evaluation.

\subsubsection{Semen Volume and Sperm Concentration}

Sperm concentration and volume of semen ejaculated in rabbit ranges from 150 - $500 \times 10^{6} \mathrm{sperm} / \mathrm{ml}$ and $0.3-0.6 \mathrm{ml}$ respectively [4] [59]. Some factors such as diet, collection frequency, age, sequence of ejaculate and ambient temperature [60] affect semen volume and sperm concentration. [61] and [62] reported that semen volume seems to be more affected by temperature than sperm concentration. According to [12], Semen composition and volume are influenced by the size of the accessory gland which is in turn influenced by testicular testosterone production among other factors. This can be explained by the report of [51] who stated that semen is a mix of spermatozoa produced by the testes and seminal plasma secreted by the epididymis and different accessory glands, of which functions are combined at the time of ejaculation, also according to the report of [29], the accessory glands contribute to the greater part of the volume of ejaculate. It therefore means that, if these organs are small in size as a result of poor development during the animal's growth period, the composition and volume of sperm that will be secreted in the epididymis and other accessory glands which will be produced alongside with testicular testosterone by a small testes, will be influenced when compared with the production of sperm from a well-sized developed re- 
productive organs. However, other studies reported that there is positive correlation between the gonadal reserve and testicular weight [41] and body of the rabbit [44].

\subsubsection{Semen Colour}

There are some ratings for the colour of rabbit semen according to different researchers though several studies have associated color and appearance as a single parameter [63] [64], and [51]. By [58], normal semen is white, homogeneous and opalescent. According to [65], the colour of rabbit semen is white with the intensity dependent on the concentration of the sperm. He further reported that milky-white semen is the best and predominant in the rabbit and represents normal semen with good quality, while [64] reported that rabbit ejaculate is mostly milky-white but the best quality is found in creamy-white semen. For [66], the semen is often pearly white and ivory, but gray semen is considered of poor quality. Also from the research study of [67], they reported that rabbit semen is pearly-white which denote good quality while other colours are classified as poor likewise as a uniform appearance is most desirable. According to [68], yellowish semen is often contaminated with urine that is normally obtained when the temperature is too high in artificial vagina.

\section{Discussion}

The selection of breeding buck and doe is very much important aspect of breeding since good progeny is expected from both. One has to consider the breeding stock in terms of fertility, paternal and maternal instinct, milk yield, growth rate, fecundity and viability [1]. Another aspect of utmost importance is the knowledge of the semen characteristics of rabbits, such as sperm concentration, motility, vigor and the occurrence of changes in the sperm cell, and these characteristics are taken into account in both andrological examinations performed during selection for breeding, and for the assessment prior to the semen processing performed soon after collection and before practicing insemination. Breeders may be looking only for external characters, neglecting production characters, thereby breeding close relatives to increase the visual impression of homogeneity.

From the report of the researchers whose experimental studies were evaluated, rabbit semen with uniform appearance is most desirable and considered to be of a good quality. They all reported that the normal semen should be white or white colour-related, homogeneous and opalescent so it is important that rabbit breeders look out for such semen quality in buck selection for breeding.

Semen composition and volume are influenced by the size of the accessory gland which is in turn influenced by testicular testosterone production among other factors [12] hence in choosing rabbit bucks for breeding purpose, consideration should be given to the anatomy of the organs and glands. The size of the testes should not be small but well developed and the location should be inside the scrotum where the temperature will be favourable for sperm production. Consequently the choice of the breed for breeding purpose has great impact on re- 
productive prolificacy. Reports from the authors reviewed in this paper, stipulated that rabbit of medium size and weight (average breeds) are better for reproductive purpose as they exhibit good reproductive characteristics such as onset of puberty, sexual maturity ectera. From the review of their reports, it was deducted that New Zealand white is a good breed for reproductive purpose owing to their anatomy and physiological characteristics.

Puberty occurs between 4 - 6 months and it occurs earlier in smaller breeds than in larger breeds (5 - 8 months) according to the authors,, it is therefore important to pay attention to that breed of rabbit that are capable of reaching their puberty earlier so as to achieve high efficiency of production. From the Studies of some of the authors [20] [36], Sexual precocity is more developed in small or medium breeds ( $4-6$ months) than in larger breeds (5 - 8 months). It was shown from their report that the New Zealand White reaches sexual maturity at 18 weeks of age and just as the sexual maturity of the animal is dependent on the breed, so also is the Seminal characteristics which is said to vary among different breeds hence in selecting buck for reproduction, the breed of the rabbit should be considered and from this review, New Zealand white seems to have better characteristics of the factors needed for better breeding purpose.

\section{Conclusion}

Certain characteristics present in the semen of rabbit bucks are closely related to the anatomy of the rabbit genital tract and the understanding of the physiology and anatomy of these sensitive organs of reproduction in rabbit which varies greatly with breeds with emphasis on the size of their organs, age of puberty and sexual maturity, promotes high efficiency and increased production in animal breeding. The semen composition and volume are influenced by the size of the accessory glands, which in turn is influenced by testicular testosterone production, among other factors hence, in selection of buck for breeding purpose, breeders should consider factors like size of the accessory glands and semen composition which is also connected with the breed of rabbit. It is therefore of great importance for this reviewed paper to be considered as an information tool for knowledge when planning to develop rabbit production for breeding purpose.

\section{Conflicts of Interest}

The author declares no conflicts of interest regarding the publication of this paper.

\section{References}

[1] Das, S.K., Chakurkar, E.B. and Singh, N.P. (2014) Rabbit as an Alternative Source of Meat Production. Technical Bulletin No. 45, ICAR Research Complex for Goa, Old Goa-403402.

[2] Ogbuewu, I.P. (2008) Physiological Responses of Rabbits Fed Graded Levels of Neem (Azadirachta indica) Leaf Meal. Unpublished M.Sc. Thesis (B. Agric. Tech), Federal University of Technology, Owerri. 
[3] Omole, A.J., Ajasin, F.O., Oluokun, J.A. and Tiamiyu, A.K. (2007) Rabbit Farming without Tears. Green Choice Agric. Publication, Ibadan.

[4] Lebas, F., Coudert, P., Rochambeau, H., Thébault, R.G. and Rouvier, R. (1997) Reproduction. In: The Rabbit. Husbandry, Health and Production, New Revised Version, FAO, Roma, Chap. 3, 45-55.

[5] Akinmutimi, A.H., Odoemelam, U.V. and Obasiekong, S.F. (2006) Effect of Replacing Maize with Ripe Plantain and Yam Peels in the Diet of Weaner Rabbits. Journal of Animal Veterinary. Advances, 5, 737-740.

[6] Tohman, R. and Massanyi, P. (1997) Structural Changes in Testis and Epididymis after an Administration of Cadmium. University of Agriculture, Nitra, 37-52.

[7] Massanyi, P., Jancova, A. and Uhrin, V. (2000) Quantitative Microscopic Analysis of Testes and Epididymis in Apodemus flavicollis (Murridae). The 6 th Internet World Congress for Biomedical Sciences on Uropathology in Human and Experimental Tissues Symposium, Ciudad Real, 14-25 February 2000, Presentation No. 144.

[8] Murray, M.J. and Meacham, R.B. (1993) Effect of Age on Male Reproductive Function. World Journal, 11, 137-140. https://doi.org/10.1007/BF00182041

[9] Massanyi, P., Lukae, N., Hluchy, S., Slameeka, J., Jureik, R., Tohman, R. and Kovaeik, J. (1999) Seasonal Variations in the Metric Analysis of the Testis and Epididymis in Fallow-Deer (Dama dama). Folia Veterinaria, 43, 67-70.

[10] Lukae, N., Massanyi, P., Tohman, R., Slameeka, J. and Jureck, R. (2000) Histological Changes in Structure of the Testis in Fallow Deer (Dama dama). Symposium in Uropathology in Human and Experimental Tissues, 6th Internet World Congress for Biomedical Sciences, Ciudad Real, 14-25 February 2000, INABIS Paper 4.

[11] Herbert, U., Ozoje, M.O. and Adejumo, D.O. (2005) Effect of Leucaena and Gliricidia Leaf Meals on the Seminal Characteristics, Testis Weights and Seminiferous Tubule Diameters of Rabbits. Animal Research, 54, 173-178. https://doi.org/10.1051/animres:2005017

[12] Campos, A.C.N., Gadelha, C.R.F., Guerreiro, M.E.F., Pereira, E.S., Lima, I.C.S., Linard, M.A.B., Meneses, H.M., Castelo-Branco, K.F. and Estevam, F.N.L. (2014) Male Rabbit Reproductive Physiology. Standard Research Journal of Agricultural Sciences, 2, 120-128.

[13] Capello, V. and Lennox, A.M. (2006) Gross and Surgical Anatomy of the Reproductive Tract of Selected Exotic Pet Mammals. Association of Avian Veterinarians, Teaneck, 19-28.

[14] Donnelly, T.M. (2004) Section 2: Rabbit. Basic Anatomy, Physiology and Husbandry. In: Quesenberry, K.E. and Carpenter, J.W., Eds., Ferrets, Rabbits and Rodents. Clinical Medicine and Surgery, Elsevier, Philadelphia, 136-146. https://doi.org/10.1016/B0-72-169377-6/50015-0

[15] Alvariño, M.R. (1993) Control de la reproducción en el conejo. Ediciones Mundi Presa, Madrid.

[16] Brewer, N.R. (2006) Historical Special Topic Overview on Rabbit Comparative Biology: Biology of the Rabbit. Journal of American Association, 45, 8-24.

[17] Holtz, W. and Foote, H. (1978) The Anatomy of the Reproduction System in Male Dutch Rabbits (Oryctolagus cuniculus) with Special Emphasis on the Accessory Sex Glands. Journal of Morphology, 158, 1-20. https://doi.org/10.1002/jmor.1051580102

[18] Turner, T.T. and Reich, G.W. (1985) Cauda Epididymidal Sperm Motility: A Comparison among Five Species. Biology of Reproduction, 32, 120-128. https://doi.org/10.1095/biolreprod32.1.120 
[19] Castro, A.C.S., Berndtson, W.E. and Cardoso, F.M. (2002) Plasma and Testicular Testosterone Levels, Volume Density and Number of Leydig Cells and Spermatogenic Efficiency of Rabbits. Brazilian Journal of Medical Biological Research, 35, 493-498. https://doi.org/10.1590/S0100-879X2002000400014

[20] Chubb, C., Ewing, L., Irby, D. and Desjardins, C. (1978) Testicular Maturation in the Rabbit: Secretion of Testosterone, Dihydrotestosterone, $5 \alpha$-Androstan- $3 \alpha, 17 \beta$-Diol and $5 \alpha$-Androstan- $\beta, 17 \beta$-Diol by Perfused Rabbit Testes-Epididymides and Spermatogenesis. Biology of Reproduction, 18, 212-218. https://doi.org/10.1095/biolreprod18.2.212

[21] Morton, D. (2006) The Use of Rabbits in Male Reproductive Toxicology. Environmental Health Perspectives, 77, 5-9. https://doi.org/10.1289/ehp.88775

[22] Richardson, V.C.G. (2003) Rabbits: Health, Husbandry, and Diseases. 178.

[23] Fraser, K.W. (1988) Reproductive Biology of Rabbits, Oryctolagus cuniculus (L.), in Central Otago, New Zealand. New Zealand Journal of Ecology, 11, 79-88.

[24] Holtz, W. and Foote, H. (1978) Composition of Rabbit Semen and the Origin of Several Constituents. Biology of Reproduction, 18, 286-292. https://doi.org/10.1095/biolreprod18.2.286

[25] Foote, R.H. and Hare, E. (2000) High Catalase Content of Rabbit Semen Appears to Be Inherited. Journal of Andrology, 21, 664-668.

[26] Foote, R.H., Draddy, P.J., Breite, M. and Oltenacu, E.A.B. (1977) Action of Androgen and Estrone Implants on Sexual Behavior and Reproductive Organs of Castrated Male Rabbits. Hormones and Behavior, 9, 57-68. https://doi.org/10.1016/0018-506X(77)90050-2

[27] Dimitrov, R.S. and Stamatova, K. (2011) Comparative Ultrasonographic Study of the Prostate Complex and Bulbourethral Glands of the Domestic Rabbit (Oryctolagus cuniculus). Journal of Veterinary Research and Animal Science, 35, 201 -205.

[28] Vásquez, B. and Del Sol, M. (2002) Complejo prostático en el conejo (Oryctolagus cuniculus). Revista Chilena de Anatomia, 2, 175-180. https://doi.org/10.4067/S0716-98682002000200010

[29] Hafez, E.S.E. (1995) Reprodução animal. 6th Edition, Manole, São Paulo.

[30] Dimitrov, R.S. (2010) Computed Tomography Imaging of the Prostate Gland in the Rabbit (Oryctolagus cuniculus). Veterinarski Arhiv, 80, 771-778.

[31] Vásquez, B. and Del Sol, M. (2001) Estudio morfológico de la glandula bulbouretral de conejo (Oryctolagus cuniculus). Revista Chilena de Anatomia, 19, 221-228. https://doi.org/10.4067/S0716-98682001000200015

[32] Fielding (1991) The Tropical Agriculturist CTA. 2nd Edition, Macmillan Education, London.

[33] Skinner, J.D. (1967) Puberty in the Male Rabbit. Journal of Reproduction and Fertility, 14, 151-154. https://doi.org/10.1530/jrf.0.0140151

[34] Amann, R.P. and Lambiase, J.T. (1967) The Male Rabbit: I. Changes in Semen Characteristics and Sperm Output between Puberty and One Year of Age. Journal of Reproduction and Fertility, 14, 329-332. https://doi.org/10.1530/jrf.0.0140329

[35] Lebas, F., Countdert, P., Rouvier, R. and De Rochanmbeau, H. (1986) The Rabbit Husbandry, Health and Production. FAO Animal Production and Health Series, Rome, No. 21, 235-237.

[36] Frame, S.R., Hurtt, M.E. and Green, J.W. (1994) Testicular Maturation in Prepubertal New Zealand White Rabbits. Veterinary Pathology, 31, 541-545. https://doi.org/10.1177/030098589403100505

[37] Egbuka, D.O. (1995) Effects of Male Presence and Mounting on the Induction of 
Ovulation and Success Rate of Artificial Insemination in Rabbits. B. Agric. Tech. Project Report, Federal University of Technology, Owerri.

[38] Hua, K.W., Zheng, G.U., Ning, J.L. and Tso, K.J. (2000) Temperature Dependent Expression of cdc2 and cycling B1 in Spermatogenic Cells during Spermatogenesis. Cell Research, 10, 289-302. https://doi.org/10.1038/sj.cr.7290056

[39] Swierstra, E.E. and Foote, R.H. (1963) Cytology and Kinetics of Spermatogenesis in the Rabbit. Journal of Reproduction and Fertility, 5, 309-322.

https://doi.org/10.1530/jrf.0.0050309

[40] Zhang, R.D., Wen, X.H., Kong, L.S., Deng, X.Z., Peng, B., Huang, A.P., Wan, Y. and Yang, Z.W. (2002) A Quantitative (Stereological) Study of the Effects of Experimental Unilateral Cryptorchidism and Subsequent Orchiopexy on Spermatogenesis in Adult Rabbit Testis. Reproduction, 124, 95-105. https://doi.org/10.1530/reprod/124.1.95

[41] Orgebin-Crist, M.C. (1968) Gonadal and Epididymal Sperm Reserves in the Rabbit: Estimation of the Daily Sperm Production. Journal of Reproduction and Fertility, 15, 15-25. https://doi.org/10.1530/jrf.0.0150015

[42] Holtz, W. and Foote, H. (1972) Sperm Production, Output and Urinary Loss in the Rabbit. Proceedings of the Society for Experimental Biology and Medicine, 141, 958-962. https://doi.org/10.3181/00379727-141-36910

[43] Amann, R.P. and Lambiase, J.T. (1969) The Male Rabbit. III. Determination of Daily Sperm Production by Means of Testicular Homogenates. Journal of Animal Science, 28, 369-374. https://doi.org/10.2527/jas1969.283369x

[44] Ewuola, E. and Egbunike, G.N. (2010) Gonadal and Extra-Gonadal Sperm Reserves and Sperm Production of Pubertal Rabbits Fed Dietary Fumonisin B. Animal Reproduction Science, 119, 282-286. https://doi.org/10.1016/j.anireprosci.2009.12.001

[45] Chrenek, P., Trandzik, J., Massanyi, P., Makarevich, A., Lukac, N., Peskovicova, D. and Paleyanda, R. (2007) Effect of Transgenesis on Reproductive Traits of Rabbit Males. Animal Reproduction Science, 99, 127-134. https://doi.org/10.1016/j.anireprosci.2006.04.052

[46] Holt, W.V. and Van Look, K.J.W. (2004) Concepts in Sperm Heterogeneity, Sperm Selection and Sperm Competition as Biological Foundations for Laboratory Tests of semen Quality. Reproduction, 127, 527-535. https://doi.org/10.1530/rep.1.00134

[47] Lavara, R., García, M.L., Torres, C., Vicente, J.S. and Baselga, M. (2008) Genetic Parameters for Semen Traits of Rabbit Males: II. Motility. Proceedings of the 9 th World Rabbit Congress, Verona, 159-162.

[48] Hagen, D.R., Gilkey, A.L. and Foote, R.H. (2002) Spermatozoal Velocity and Motility and Relationship to Fertility in the Rabbit Inseminated with Low Sperm Numbers. World Rabbit Science, 10, 135-140. https://doi.org/10.4995/wrs.2002.485

[49] Lavara, R., Vicente, J.S., Marco-Jiménez, F. and Baselga, M. (2008) Correlation between Casa and Asma Parameters in Rabbit Semen. Proceedings of the 9 th World Rabbit Congress, Verona, 381-385.

[50] Mukherjee, D., Johari, M. and Bhattacharya, P. (1951) The Gelatinous Mass in Rabbit Semen. Nature, 168, 422-423. https://doi.org/10.1038/168422b0

[51] El-Azim, A.A. and El-kamash, E.M. (2011) Evaluation of Semen Quality and Its Relation to Mating System for Some Breeds of Rabbits under Environmental Conditions in the Middle of Egypt. Egyptian Poultry Science Journal, 31, 467-480.

[52] Castellini, C., Lattaioli, P., Moroni, M. and Minelli, A. (2000) Effect of Seminal Plasma on the Characteristics and Fertility of Rabbit Spermatozoa. Animal Reproduction Science, 63, 275-282. https://doi.org/10.1016/S0378-4320(00)00181-0 
[53] Zaniboni, L., Gliozzi, T., Maldjia, A., Luzi, F. and Cerolini, S. (2004) Fatty Acid and Tocopherol Composition of Semen Components in the Rabbit. Proceedings of the 8 th World Rabbit Congress, Puebla, 365-370.

[54] Castellini, C., Mourvaki, E., Dal Bosco, A. and Galli, F. (2007) Vitamin E Biochemistry and Function: A Case Study in Male Rabbit. Reproduction in Domestic Animals Journal, 42, 248-256. https://doi.org/10.1111/j.1439-0531.2006.00760.x

[55] Lukáč, N., Massányi, P., Kročkova, J., Na, P., Slamečka, J., Ondruška, L., Formicki, G. and Trandžík, J. (2009) Relationship between Trace Element Concentrations and Spermatozoa Quality in Rabbit Semen. Slovak Journal of Animal Science, 42, 46-50.

[56] Del Niño Jesus, A., Muñoz, L., Josa, A., Espinosa, E., Gracia, M., Martinez, G. and Leuza, M.P. (1997) Modifications of Some Parameters of the Rabbit Ejaculate after Ablation of the Vesicular Gland. World Rabbit Science, 5, 3-5.

https://doi.org/10.4995/wrs.1997.310

[57] Bell, D.J. and Mitchell, S. (1984) Effects of Female Urine on Growth and Sexual Maturation in Male Rabbits. Journal of Reproduction and Fertility, 71, 155-160. https://doi.org/10.1530/jrf.0.0710155

[58] IRRG Guidelines, International Rabbit Reproduction Group (2005) Guidelines for the Handling of Rabbit Bucks and Semen. World Rabbit Science, 13, 71-91. https://doi.org/10.4995/wrs.2005.527

[59] Adams, C.E. and Singh, M.M. (1981) Semen Characteristics and Fertility of Rabbits Subjected to Exhaustive Use. Laboratory Animals, 15, 157-161. https://doi.org/10.1258/002367781780958856

[60] Finzi, A., Morera, P. and Macchioni, P. (1994) Modifications of Some Rabbit Spermatic Parameters in Relationship to High Ambient Temperatures. Cahiers Options Méditerranéennes, 8, 333-336.

[61] García-Tomás, M., Tusell, L.I., López-Béjar, M., Ramon, O.J. and Rafel, M. (2008) Influence of Environmental Temperature and Relative Humidity on Quantitative and Qualitative Semen Traits of Rabbits. Proceedings of the 9 th World Rabbit Congress, Verona, 359-363.

[62] Roca, J., Martínez, S., Orengo, J., Parrilla, I., Vazquez, J.M. and Martinez, E.A. (2005) Influence of Constant Long Days on Ejaculate Parameters of Rabbits Reared under Natural Environment Conditions of Mediterranean Area. Livestock Production Science, 94, 169-177. https://doi.org/10.1016/j.livprodsci.2004.10.011

[63] Scapinello, C., Moraes, G.V., Souza, M.L.R., Andreazzi, M.A. and Antunes, E.B. (1997) Influência de diferentes níveis de metionina + cistina sobre a produção de sêmen de coelhos Nova Zelândia Branco. Revista UNIMAR, 19, 923-931.

[64] Mataveli, M. (2008) Níveis de selênio na dieta de coelhos e a influência na qualidade e nos métodos de conservação do semen. Unpublished Thesis of Master, State University of Maringá.

[65] Alvarez, C.A., Moraes, G., Scapinello, C., Martins, E.N., Cardozo, R.M., Mataveli, M. and Kioshima, R.S. (2006) Efeito da suplementação de selenometionina e vitamina C sobre as características quantitativas e qualitativas do sêmen de coelho. Acta Scientiarum: Animal Sciences, 28, 177-185. https://doi.org/10.4025/actascianimsci.v28i2.654

[66] Bilbao, M.M. (1996) Manejo en inseminación artificial: Factores que afectan a la calidad seminal y al indice de fertilidad. Boletin de Cunicultura, 85, 45-56.

[67] Arrebola, D.F.A. and Fernández, L.A.R. (2011) Analysis of Seminal Quality, a Tool in Fertility Experimental Toxicology Study. Revista de Toxicologia en Linea, 39-50.

[68] Chang, M.C. (1959) Fertilizing Capacity of Spermatozoa. In: Recent Progress in the Endocrinology of Reproduction, Academic Press, New York, 131. 